\title{
Граматички деривати глагола любить у контексту видске (не)парности и валентности (са кратким освртом на еквиваленте у српском језику)
}

\section{Grammatical Derivatives of the Verb Ljubit' in the Context of Aspectual Pairness and Valency (with a Short Overview on the Translational Equivalents in Serbian)}

Тијана Балек

(Нови Сад, Србија)

\section{Апстракт:}

Истраживање је посвећено граматичким (махом префиксалним) изведеницама руског глагола любить. Оно је посебно фокусирано на видску (не)парност деривата наведеног глагола регистрованих у релевантним речницима руског језика, као и на њихове валенцијске особине. Добијени резултати указују на то да су посматрани глаголи углавном двовалентни; као и да се међу анализираним јединицама налазе различити случајеви у погледу видске кореспонденције. Другим речима, присутни су како видски парни глаголи попут влюбить (ся) - влюблять (ся), али и они који припадају једновидским (као и мотивни любить): неgолюбливать и полюбить(ся). Српски еквиваленти често показују аналитизам, што условљава преводну асиметрију која је такође размотрена у раду.

\section{Кључне речи:}

деривати глагола любить; видска (не)парност; валентност; емоционални односи; руски језик; српски еквиваленти 


\section{Abstract:}

The paper describes grammatical (mostly prefixed) derivatives of the Russian verb ljubit'. It is specially focused on aspectual pairness of the derivatives of the given verb registered in relevant Russian dictionaries, as well as on valency of the derivatives. Obtained results show that analyzed verbs are mostly bivalent and that there are different cases of the aspectual pairness. In other words, there are aspectual pairs such as vljubit'(sja) - vljublat'(sja), but there are also verbs without aspectual pair (just like motive verb ljubit'): nedoljublivat' and poljubit'(sja). Serbian equivalents show analyticism, conditioning translational asymmetry.

\section{Key words:}

derivatives of the verb ljubit'; aspectual pairness; valency; emotional relations; Russian language; Serbian equivalents

Предмет датог рада јесте анализа граматичких деривата глагола любить у руском језику у контексту видске (не)парности и валенцијских карактеристика, а коментаришу се и особине глагола који представљају њихове преводне еквиваленте у српском језику. Дакле, будући да творбени опсег лексеме любить није претерано широк, у фокусу нашег рада су регистроване граматичке изведенице настале помоћу следећих префикса: неgо- (недолюбливать), йо- (полюбить (ся)), в- (влюбить (ся) - влюблять (ся)) и раз- (разлюбить (ся) - разлюблять (ся)). Најпре треба указати на чињеницу да се, без обзира на готово идентичан семантички садржај глагола любить у поређењу са српским глаголом волети, који се могу сматрати и прототипичним представницима глагола емоционалног садржаја са позитивним значењем ${ }^{1}$, у руском језику користе, када је реч о граматичким дериватима, сасвим другачији деривациони афикси (неки од њих се у српском језику не јављају са еквивалентним основама (или су пак такви случајеви ретки), те се стога употребљавају аналитичке конструкције, што ће у наставку бити показано). Дата околност условљава знатну преводну асиметрију, а то ће такође бити размотрено.

Класификација глагола любить унутар глаголске лексике са емоционалним значењем није уједначена. Наиме, дати глагол, са једне стране, сврстава се у класу глагола којима се денотирају емоционални односи ${ }^{2}$, чије је

1 BALEK, T.: Morfosintaksičke i pragmatičke osobine glagola ljubit'(sja) $i$ voleti (se) kao eksponenata glagola sa značenjem pozitivnih osećanja u ruskom i srpskom jeziku. Philologia Mediana, 2021, br. 13, S. 739-755.

2 IORDANSKAJA, L. N.: Popytka leksikografičeskogo tolkovanija gruppy russkich slov so značenijem čuvstva. Mašinnyj perevod i prikladnaja lingvistika, 1970, № 3, s. 3-26. PADUČEVA, Je. V.: Dinamičeskije modeli $v$ semantike leksiki. Moskva: Jazyki slavjanskoj kul'tury, 2004. 
категоријално обележје осећање одрећеног емоционалног односа према некоме или нечему, тј. емоционална повезаност човека са другим људима, предметима, појавама итд ${ }^{3}$. С друге пак стране, глагол любuть, као и други који припадају семантичкој парадигми у којој је наведена лексема типични члан, заузимају међупозицију у односу на глаголе са значењем емоционалног преживљавања и емоционалног односа ${ }^{4}$. Сматрамо да граматичке изведенице задржавају дату релацију. Дакле, с обзиром на то да, како је горе истакнуто, творбени опсег глагола любить није нарочито продуктиван, он представља мотивациону базу за образовање следећих глагола с модификованом семантиком: једновидских глагола недолюбливать, полюбить и полюбиться, као и видских парова влюбить : влюблять, влюбляться : влюбиться и разлюбить : разлюблять, односно

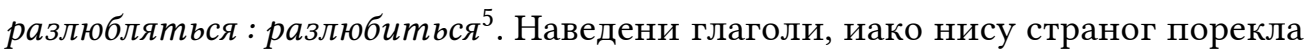
и не одликују се стилском маркираношћу ${ }^{6}$, према подацима Националноі корӣyса рускої језика који су наведени у даљем тексту рада, немају знатан удео у активном лексичком фонду руског језика.

Анализу започињемо изведеницама са префиксом в-, односно видским паром влюбить : влюблять и његовом варијантном рефлексивном формом влюбляться : влюбиться. Наиме, нерефлексивни видски пар поседује, према подацима доступним у четворотомном Речнику рускої језика ${ }^{7}$ Руске Академије наука, веома просту дефиницију, уп.: Влюбить (несов. влюблять). - Заставить полюбить, увлечься. Међутим, незнатно сложенијом семантиком одликује се рефлексивна форма: Влюбиться - (несов. влюбляться). Почувствовать любовное влечение к кому-л. || Увлечься чем-л., поддаться очарованию чеїо-л. ${ }^{8}$. Сличне дефиниције посматраних лексема доступне су и у седамнаестотомном

3 DOVGAL', A. V. - ŠEPELEVA, Ju. A.: Semantičeskije osobennosti glagolov so značenijami 'èmocional'noje sostojanije' $i$ 'èmocional'noje otnošenije' v anglijskom jazyke. In: Val'tèr, Ch. et al. (ed.): Acta Germano-Slavica. Mahileŭ: MhDU, 2015, № 6, s. 49.

4 VASIL'JEV, L. M.: Semantika russkogo glagola. Moskva: Vysšaja škola, 1981, s. 108.

5 TICHONOV, A. N.: Novyj slovoobrazovatel'nyj slovar' russkogo jazyka. Moskva: AST, 2014.

6 Према JEVGEN'JEVA, A. P.: Slovar' russkogo jazyka: v 4-ch tomach. Moskva: Russkij jazyk Poligrafresursy, 1999. <http://feb-web.ru/feb/mas/mas-abc/default.asp >. [online]. [cit. 1. 8. 2021]. С друге стране, као разговорне форме регистровани су глаголи полюбиться, разлюбить, разлюбиться, разлюблять и разлюбляться (ČERNYŠEV, V. I.: Slovar' sovremennogo russkogo literaturnogo jazyka. Moskva-Leningrad: Iz-vo Akademii Nauk SSSR, 1960, t. 10, s. 1146.; ČERNYŠEV, V. I.: Slovar' sovremennogo russkogo literaturnogo jazyka. Moskva-Leningrad: Iz-vo Akademii Nauk SSSR, 1961, t. 12, s. 369.).

7 JEVGEN'JEVA, A. P.: Slovar' russkogo jazyka: $v$ 4-ch tomach. Moskva: Russkij jazyk - Poligrafresursy, 1999. <http://feb-web.ru/feb/mas/mas-abc/default.asp>. [online]. [cit. 1. 8. 2021]. Ibidem. 
Речнику савременої рускої књижевноі језика ${ }^{9}$. Наведеним глаголским паровима у преводу на српски језик не одговара нити један дериват лексеме волети. Наиме, пар влюбить : влюблять се на српски језик (формално) преводи перифрастичном конструкцијом са значењем изазивања код кога позитивно

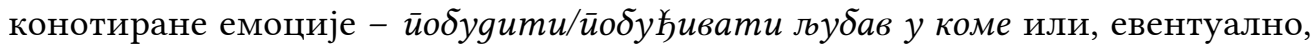
залуgети кої ${ }^{10}$. Са друге стране, видском пару са рефлексивним маркером (постфиксом -ся) влюбляться : влюбиться у српском језику одговара видски пар зальубливати се : зальубити се ${ }^{11}$, односно, како видимо, у конкретном случају се у српском језику не употребљава глагол настао од именице вољь $a^{12}$ (како је код

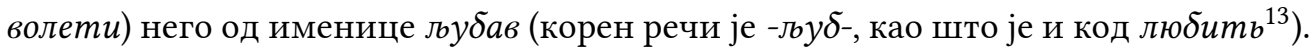
Уп. нпр.: (1) В это время Левин часто бывал в доме Щербацких и влюбился в дом Щербацких ${ }^{14}$. // У то време Љевин је често о олазио у кућу Шчербацкима, и заљубио се $у$ my кућу⿰氵 ${ }^{15}$; (2) Во время своего студенчества он чуть было не влюбился в старшую, Долли, но ее вскоре выдали замуж за Облонского. // Као стуудент умало се није заљубио у најстарију, Доли; њу убрзо уgаgоше за Облонскої; (3) - Ты пойми, - сказал он, - что это не любовь. Я был влюблен, но это не то. // - Разумеј ме - йоче он. - Ово није љубав. Ја сам и раније бивао заљубљен, али ово је gруїо; (4) - Ну-с, он появился здесь вскоре после тебя, и, как я понимаю, он по уши влюблен в Кити... // - Овамо је gошао Вронски убрзо йосле твоїа одласка, и, како ми се чини, до ушију се заљубио у Кити...

Као што можемо видети, у примерима на српском језику (било да су употребљене рефлексивне или нерефлексивне форме руских глаголских облика) глагол заљубити се доминантан је преводни еквивалент, што потврђује да се приликом преношења значења ових лексема у српском језику чешће користе глаголи с кореном -љь $\delta$-. Када је пак реч о валенцијским особинама наведених глагола, запажа се да они могу бити како једновалентни (у оним

9 ČERNYŠEV, V. I.: Slovar' sovremennogo russkogo literaturnogo jazyka. Moskva-Leningrad: Iz-vo Akademii Nauk SSSR, 1951, t. 2, s. 455-457.

10 STANKOVIĆ, B.: Rusko-srpski rečnik. Novi Sad: Prometej, 2008, s. 85.

11 Ibidem.

12 SKOK, P.: Etimologijski rječnik hrvatskoga ili srpskoga jezika. Knjiga treća poni ${ }^{2}$ - Ž. Zagreb: Jugoslavenska akademija znanosti i umjetnosti, 1973, s. 614.

13 SKOK, P.: Etimologijski rječnik hrvatskoga ili srpskoga jezika. Knjiga druga $\mathrm{K}$ - poni ${ }^{1}$. Zagreb: Jugoslavenska akademija znanosti i umjetnosti, 1972, s. 337-339.

14 Примери на руском језику у даљем тексту рада (осим ако је наведено другачије) преузети су из: TOLSTOJ, L. N.: Anna Karenina. <https://ilibrary.ru/text/1099/index.html>. [online]. [cit. 7. 7 . 2021].

15 Уколико није друкчије назначено, примери на српском језику преузети су из: TOLSTOJ, L. N.: Ana Karenjina. <http://www.umetnickaskolanis.com/wp-content/uploads/2017/09/Lav-Nikolajevic\% CC\%8C-Tolstoj-Ana-Karenjina.pdf>. [online]. [cit. 7. 7. 2021]. 
случајевима када се констатује да неко осећа позитивну емоцију (експеријент), али онај ка коме је емоција упућена (реципијент) није назначен у исказу) ${ }^{16}$ тако и двовалентни (уколико је појам ка којем је осећање усмерено лексикализован). Наравно, позитивно осећање може бити усмерено и на инаниматан појам: предмет, идеју и сл. ${ }^{17}$ Уп.: (5) Уж не влюбился ли я в самом деле ${ }^{18}$; (6) A младший - безумно влюбился в Алису Селезневу ${ }^{19}$; (7) Я влюбилась в историю этой пары... ${ }^{20}$; (8) В меня там влюбился бандит, проходу не давал, пришлось убегать ${ }^{21}$; (9) - Как пришло решение открыть бизнес? - Конкретно с «Партией еды»: а) когда я влюбился в саму идею; б) когда нашел партнеров под проект. Между а) и б) прошло примерно полгода $a^{22}$; (10) Тогда я в это дело влюбился, стал дальше изучать и понял, что нашел пустую нишу: $9 о$ процентов людей страдают мышечной недостаточностью как минимум третьей степени ${ }^{23}$.

Наиме, како показују наведени примери, уколико објекат ка којем је усмерено позитивно осећање није лексикализован, реч је о тзв. општефактичком значењу којим се констатује присуство чега, општа чињеница (у нашем случају - осећање љубави) и глагол је једновалентан. Уколико је пак у исказу назначен дати објекат/реципијент љубави, тада је он обавезно граматикализован акузативом с предлогом 6 , а семантички аналогну конструкцију у српском језику представља акузатив са предлогом $y$. Међутим, без обзира на то што су у наведеним примерима глаголске лексеме у руском језику рефлексивне, реципрочност (узајамно осећање љубави) није присутна јер ју је у руском језику потребно (додатно) лексички маркирати. У ту сврху може се употребити сложена узајамно-повратна заменица друг друга (срп. јеgно gруїо, међусобно и сл.): (11) Это была стройная, очаровательная девушка, и весь радостный облик её струил ласку на окружающий мир. Мь влюбились друг в друга ${ }^{24}$; (12) Итак,

16 На пример Я влюбился. Оваква употреба је ретка јер је обично реципијент/објекат осећања назначен.

17 Уп. и сегмент из горенаведених примера влюбился в дом Щербацики // заљубио се у ту $\kappa y \hbar y$.

18 NACIONAL'NYF KORPUS RUSSKOGO JAZYKA. <https://ruscorpora.ru/new/>. [online]. [cit. 1. 8. 2021].

19 Ibidem.

20 Ibidem.

21 Ibidem.

22 Ibidem.

23 Ibidem.

24 Ibidem. 
бабушка в девушках жила в Гомеле, работала в парикмахерской, где-то они с дедушкой встретились, влюбились друг в друга и решили пожениться ${ }^{25}$.

Нерефлексивна форма глагола влюблять користи се и у случајевима када се жели посебно истаћи да је у некоме изазвано осећање љубави, и тада се може допуна граматикализовати и беспредлошким акузативом ${ }^{26}$, премда је акузатив с предлогом в чешће у употреби. Посматрани руски глаголи јављају се и у изразима типа Влюбляться : влюбиться без памяти / по уши (срп. заљубльвати се : залубити се gо/ӣреко ушију; gо безумности и сл.), којима се описује велики интензитет позитивно конотираног осећања (в. и горенаведене примере). На основу изложеног може се закључити да се посматрани видски парови, осим хомонимије и преводне асиметрије, не одликују посебним карактеристикама нити семантичке нити синтаксичке природе.

Знатно интересантнији за анализу јесу (не)рефлексивни видски парови разлюбить (ся) : разлюблять $(с я)^{27}$, којима се денотира йрестанак осећања љубави према коме/чему. Ови се парови у Речнику савременої рускої књижевноі језика 28 дефинишу веома једноставно: Переставать любить, кого-, что-либо, односно Об исчезновении чувства любви у кого-либо. Главна специфичност датих руских глаголских лексема састоји се у томе што се њихово значење у српском језику мора изразити аналитички јер не постоји одговарајућа лексема којом би се престанак љубави на адекватан начин описао. То се, наиме, у српском језику може постићи предикатом у чијем су саставу глаголи ӣpecmamu, који има граматичко значење свршеног вида и у датом споју је синсемантичан и носи обележје фазности (тачније, достизања крајње тачке у вршењу радње), и волети, са граматичким значењем несвршеног вида ${ }^{29}$ у функцији управног члана и семантичког тежишта предикатске јединице. ${ }^{30}$ Осим тога, престанак радње денотиране руским глаголима разлюбить(ся) : разлюблять(ся) може бити изражен и уколико се употреби прилог вище у темпоралном значењу уз

25 Ibidem.

26 УП. А вот ты меня влюбил с такой великолепной лёгкостью, что и сам не заметил. У примерима овог типа имплицирана је допуна у акузативу в себя, а субјекат је логички (срп. заљубио си ме у себе). Дата конструкција се у руском језику такође често среће.

27 Нерефлексивна глаголска лексема несвршеног вида има и секундарно имперфективизовану варијантну форму разлюбливать.

28 ČERNYŠEV, V. I.: Slovar' sovremennogo russkogo literaturnogo jazyka. Moskva-Leningrad: Iz-vo Akademii Nauk SSSR, 1961, t. 12, s. 369.

29 Заправо, доминанте низова, любить и волети, уопште немају кореспондент свршеног вида, тј. они су imperfectiva tantum.

30 С друге стране, у српском језику постоји глагол одљубити се, али не постоји *одволети. Будући да се њима изражава престанак различитих (иако позитивних) осећања, не поистовећујемо их приликом анализе. 
обавезно негиран предикат, чиме се добија комуникативна ситуација типа 'више не Х' $\rightarrow$ више не волети коїа/шта. Уп.: (11) Ей казалось, что он, зная это, скорее может разлюбить ее; // Чинило јој се, ако би он то сазнао, моїао би убрзо престати gа је воли...; (12) И вдруг ей пришла странная мысль: - что, если он разлюбил ее? // И оgјеgном је обузе чуgна мисао: а ако је он више не воли?; (13) Она думала, что он разлюбил ее, она чувствовала себя близкою к отчаянию, и вследствие этого она почувствовала себя особенно возбужденною. // Мислила је gа је он више не воли, осећала gа је близу очајања, и услеg тоїа била врло узбутена.; (14) И так же как прежде, занятиями днем и морфином по ночам она могла заглушать страшные мысли о том, что будет, если он разлюбит ее. // И, исто као и ирре, може зайлушивати gану раяом, а ноћу морфијумом страшне мисли о томе: шта ће бити ако је он престане волети.

Из наведених примера се запажа да су посматрани глаголи у руском језику двовалентни, односно да се мора лексикализовати како експеријент (онај који је доживљавао прекинуто осећање љубави), тако и реципијент (особа ка којој је дато осећање било усмерено (граматикализована беспредлошким акузативом), уз напомену да се у тој позицији обавезно мора јавити аниматан објекат. У српском језику је ситуација врло слична, а разлика је једино у начину преношења семантичког садржаја руске глаголске лексеме, што је горе појашњено. Дакле, с обзиром на семантичке специфичности, ове бисмо глаголе могли посматрати и као прелазну фазу од глагола емоционалних односа ка глаголима емоционалних стања.

Поред анализираних видских парова, глагол любить јавља се као мотиватор за настанак једновидских глагола, односно глагола који немају видски кореспондент супротне граматичке (видске) садржине. Реч је о полюбить(ся), који поседује само свршени вид (perfectiva tantum), и о недолюбливать, који поседује само несвршени вид (imperfectiva tantum).

У погледу семантичког садржаја глагол полюбить $(c я)^{31}$ је веома сличан глаголу заволети (се) у српском језику, односно ове две речи су регистроване

31 Полюбить има укупно 4 значења (ČERNYŠEV, V. I.: Slovar' sovremennogo russkogo literaturnogo jazyka. Moskva-Leningrad: Iz-vo Akademii Nauk SSSR, 1960, t. 10, s. 1145-1146.): 1. Почувствовать глубокую привязанность, преданность к кому-, чему-либо, признавая высокое значение, достоинство и т. п. кого-, чего-либо. || Почувствовать склонность, привязанность к кому-либо вследствие близкого родства, дружбы, товарищества и т. п. 2. Почувствовать горячую сердечную склонность, влечение к лицу другого пола. 3. Почувствовать внутреннее влечение, склонность, тяготение к чему-либо. II Испытывая удовольствие (от созерцания, ощущения чего-либо), привыкнуть, привязаться к чему-либо. || Пристраститься к чему-либо; отдать предпочтение. \| Оценить, признать что-либо. 4. Предпочесть что-либо как наилучшее условие своего существования, обитания. О животных. Уп. такође и: Полюбиться (ČERNYŠEV, V. I.: Slovar' sovremennogo russkogo literaturnogo jazyka. Moskva-Leningrad: Iz-vo Akademii Nauk SSSR, 1960, t. 10, s. 1146-1147.): 1. Разг. Понравиться кому-либо, прийтись 
као прави преводни еквиваленти ${ }^{32}$, те су у својеврсном хетеронимском односу, премда се и у датом случају ради о глаголима с различитим кореном (в. горе). Осим тога, потребно је рећи да у српском језику постоји хомонимски пар глаголу полюбить - глагол ӣольубитu, који подразумева физичку манифестацију осећања љубави, односно додир уснама (пољубац). Са друге стране, наведеном српском глаголу йољубити у руском језику одговара лексема поцеловать. Ипак, без обзира на сличност семантичких садржаја лексема-хетеронима у руском (полюбить) и српском језику (заволети), према нашој интерпретацији извесне разлике постоје у њиховој акционалној припадности, што се очитује у погледу маркирања трајања глаголом денотиране ситуације у порећеним језицима. Наиме, у српском језику је реч о инхоативном глаголу којим се маркира прва, почетна фаза у вршењу одређене радње која затим имплицитно наставља да се одвија у времену. У руском пак језику, што се лако може закључити из дате речничке одреднице, изостаје одређење типа ӣочети осећати $X$, дакле нема компоненте почетности већ делимитативности (ограничености) радње. Другим речима, трајање глаголом денотиране ситуације се маркира као кратко, али нема података о наставку дате ситуације како је код инхоативних глагола. Ипак, како показују примери, одсуство те компоненте не утиче на инхоативну интерпретацију глагола йолюбить приликом превода на српски језик. Уп.: (15) Он полюбил Голенищева за это замечание и от состояния уныния вдруг перешел к восторгу. // Он заволе Голенишчева збоі те найомене, и из сете ирете одједном у одушевљене.; (16) Одеваясь, она занялась больше, чем все эти дни, своим туалетом, как будто он мог, разлюбив ее, опять полюбить за то, что на ней будет то платье и та прическа, которые больше шли к ней. // Облачећи се йазила је на своју тоалету више неїо йослеgюих дана, као gа би је он моїао, ако је више не воли, йоново заволети зато што ће на юој бити она хаљина и она фризура која јој најлеитше стоји.; (17) - Да, но в ней нет этой действительности, как во мне; я понимаю, что он меня никогда бы не полюбил. Она вся духовная... // - Да, али у юој нема оне стварности као у мени; уверена сам gа он мене никаg не би заволео. Она је сва духовна.; (18) - Но не так, как с Николенькой покойным... вы полюбили друг друга, - докончил Левин. // - Али није тако као с йокојним Николицом... вас gвоје сте се заволели - gоврии Љевин. У примеру (16) могућа је инхоативна интерпретација руског глагола полюбить, као и његовог еквивалента у српском језику заволети, искључиво зато што су дати адвербијали времена опять односно йоново, којима се маркира поновно

по вкусу. 2. Простореч. Полюбить (во 2-м знач.) друг друга. 3. Безл. Простореч. Пришлось, придется полюбить.

32 STANKOVIĆ, B.: Rusko-srpski rečnik. Novi Sad: Prometej, 2008, s. 599. 
извршење глаголом денотиране ситуације (испочетка, понављање почетне фазе у осећању љубави). Као код многих претходно анализираних лексема у руском језику, рефлексивност глагола не имплицира обавезну реципрочност у погледу осећања љубави, већ ју је неопходно лексикализовати сложеном узајамно-повратном заменицом друг друга. Валенцијски потенцијал глагола полюбить и његове рефлексивне форме није нарочито развијен. Наиме, они су двовалентни и агенси су најчешће аниматни, а реципијент позитивног осећања граматикализује се акузативом без предлога. Ипак, уколико је агенс животиња а позитивно осећање се односи на станиште/средину у којој она борави, тада је објекат, природно, инаниматан (истоветно значење присутно је и код глагола волети у српском језику): (19) Никто уже не живет там, и только видны по песку следы оленей, бирюков, зайцев и фазанов, полюбивших эти места ${ }^{33}$.

Последњи дериват глагола любить који се подвргава анализи јесте једновидски глагол несвршеног вида недолюбливать, који се, условно речено, налази на прелазном стадијуму од лексема са позитивно конотираним семантичким емоционалним садржајем ка онима које имају негативну семантику. Недолюбливать, наиме, има само једно значење, и то: Чувствовать некоторую неприязнь, нерасположение к кому-, чему-либо ${ }^{34}$; а на српски језик се најчешће преводи описно - не трӣети, не волети коїа, бити несклон, ненаклоюен $\kappa о м e^{35}$. Иако се, с обзиром на не претерано речнички спецификован семантички садржај ове глаголске лексеме (уп. неодређену заменицу у оквиру саме дефиниције - некоторую неприязнь), он може тумачити и као позитиван и као негативан, сматрамо да је, барем без додатних екстралингвистичких фактора, чешће негативан. У примеру (20) употребљен је и израз блаїо іоворећи (рус. мягко говоря) који помаже да се ситуација процени као каузатор негативних осећања ${ }^{36}$, па је приликом преноса значења на српски језик ${ }^{37}$ могуће употребити негиране

33 Пример је преузет из речничке одреднице дате у: ČERNYŠEV, V. I.: Slovar' sovremennogo russkogo literaturnogo jazyka. Moskva-Leningrad: Iz-vo Akademii Nauk SSSR, 1960, t. 10, s. 1146.

34 ČERNYŠEV, V. I.: Slovar' sovremennogo russkogo literaturnogo jazyka. Moskva-Leningrad: Iz-vo Akademii Nauk SSSR, 1958, t. 7, s. 826.

35 STANKOVIĆ, B.: Rusko-srpski rečnik. Novi Sad: Prometej, 2008, s. 407.

36 LJU, È - ŠEREMET'JEVA, Je. S.: Metatekstovyj operator «mjagko govorja»: specifika funkcionirovanija. Litera, 2021, № 5, s. 66.

37 Уп. могућа преводна решења на српском језику: (20а) Мужа алкохоличара, сина, чији је мозак створен само за војску, и пасторку коју, благо говорећи, не воли [не трпи, не подноси], посебно након што је нен син решио да је ожени (превод наш); (21а) Житель Северне престонице васпитани на предивним архитектурним обрасцима не подносе [не воле, не трпе] савремене римејкове (превод наш); (22а) Дина није подносила [није трпела, мрзела је] ту досадно бучну и неискрену жену... (превод наш); (2за) Нажалост, како кажу, не воли [не подноси, не трпи] милицију (превод наш); (24а) Био је склон мирном породичном животу и мрзео је [није подносио, није трпео] бучну уметничку боемију (превод наш). 
форме глагола волети (може се сматрати еуфемизмом у односу на облике којима се директно изражава негативан однос), трӣети или йоgносити (премда је исказан негативни емоционални однос, он је блажи у односу на глагол мрзети). Дато аналогно решење применљиво је и у (22) и (23), у којем је реч о колективном реципијенту (милиция), као и у (21), где се ради о неживом појму: (20) Алкоголика мужа, сына, у которого мозг заточен только под армию, и неродную дочь, которую, мягко говоря, недолюбливает, особенно после того, как её сын решает жениться на ней; (21) Жители Северной столицы, воспитанные на прекрасных архитектурных образцах, современный новодел недолюбливают; (22) Дина недолюбливала эту назойливо-шумную и неискреннюю женщину и не поддерживала с ней отношений со дня маминой смерти, но теперь она написала ей покаянное письмо - та незамедлительно откликнулась, и завязалась оживленная переписка; (23) К сожалению, по слухам, он недолюбливает милицию; (24) Он был склонен к размеренной семейной жизни и недолюбливал шумную артистическую богему ${ }^{38}$.

Са аспекта морфемске структуре посматрани глагол припада денормативном начину глаголске радње, формално презентованом помоћу префикса неgокоји се у српском ретко користи ${ }^{39}$, а чија је одлика (из)вршење радње мање (или слабије) него што је претпостављено нормом садржаном у семантици мотивног глагола. Међутим, у анализираном случају се не ради о осећању љубави слабијег интензитета него што је то случај с глаголом любить пошто формална и садржинска страна датог префиксалног глагола нису истоветне (уп. горенаведене речничке дефиниције). Посматрани глагол је двовалентан с аниматним субјектом, док је објекат у акузативу без предлога и може имати обележја и живо и неживо, што наведени примери потврђују.

Такоће, примећено је да анализирани граматички деривати показују прагматичке разлике у односу на мотивни глагол любить, што подразумева да се они не користе као перформативи ${ }^{40}$, односно, иако се датим глаголима описује емоционални однос експеријента и реципијента или објекта, нема побуђивања на конкретну активност која се треба предузети. Поред тога, према

38 Сви примери су преузети из: NACIONAL'NYJ KORPUS RUSSKOGO JAZYKA. <https://ruscorpora. $\mathrm{ru} / \mathrm{new} />$. [online]. [cit. 1. 8. 2021]. У књижевним делима из којих су ексцерпирани илустративни примери дати глаголски облик није пронађен.

39 TOŠOVIČ, B.: Sposoby glagol'nogo dejstvija v serbskom, chorvatskom i bošnjackom jazykach. Katowice: Wydawnictwo Uniwersytetu Śląskiego, 2009, s. 86.

40 О датом аспекту употребе глагола любить и волети в. код: BALEK, T.: Morfosintaksičke i pragmatičke osobine glagola ljubit'(sja) i voleti (se) kao eksponenata glagola sa značenjem pozitivnih osećanja u ruskom i srpskom jeziku. Philologia Mediana, 2021, br. 13, s. 749-750. 
подацима из Националноі̄ корӣуса рускої језика ${ }^{41}$ може се закључити да се проучаване лексеме или не срећу у 1. лицу једнине презента индикатива (или пак футура, у зависности од вида), што је основни услов контекстуалне реализације перформатива, (ради се о разлюбиться, чија укупна фреквенција износи 4, и разлюблять (ся), где је нерефлексивна форма присутна у 14 случајева, а рефлексивна само у 2), или је пак њихова фреквенција у датом облику ниска у односу на укупан број регистрованих: влюбить (4 од 203), влюблять (3 од 56), влюбляться (73 од 1805), влюбиться (81 од 5611); разлюбить (81 од 1613). Глаголи без видског кореспондента супротне граматичке садржине следе наведени модел, те се у 1. лицу једнине презента (или футура) индикатива појављују знатно ређе у односу на укупну заступљеност. На пример, полюбить се у датом облику бележи 319 пута од укупно 12676, док се његова рефлексивна варијанта полюбиться у тој форми јавља свега у 2 примера од регистрованих 1165. Исто тако, недолюбливать је присутан у 955 примера, али само у 44 је реч о 1. лицу једнине. Српски еквиваленти посматраних изведеница се такође не употребљавају у перформативној функцији, посебно када је реч о аналитичким структурама.

Спроведена анализа граматичких изведеница глагола любить у погледу видске корелативности и њихових валенцијских карактеристика показала је да они задржавају одрећене граматичке параметре мотивне речи. Наиме, то се, пре свега, односи на њихову валентност јер су све посматране речи (како једновидски глаголи недолюбливать, полюбить и полюбиться, тако и видски парови влюбить : влюблять, влюбляться : влюбиться и разлюбить : разлюблять, односно разлюбляться : разлюбиться) двовалентне, што је својствено глаголима емоционалних односа.

Премда полазни глагол нема видски парњак, додавањем творбених афикса настају нови глаголи који такође немају парњак, било свршеног (недолюбливать) или несвршеног вида (полюбить $(c я)$ ). Заједничко свим дериватима јесте да се не јављају у функцији перформатива, док мотивни любить поседује ту могућност. Када је пак реч о еквивалентима на српском језику, често се

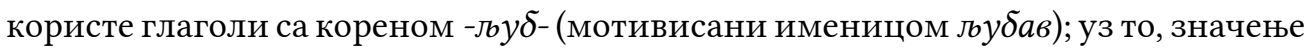
се са руског на српски представља и аналитичким конструкцијама у којима учествују и фазни глаголи са глаголом емоционалне вредности као носиоцем њиховог значења.

Своју примену резултати датог испитивања могу имати, на пример, уколико би наставак анализе био оријентисан на грађу на српском језику, односно на

41 NACIONAL'NYJ KORPUS RUSSKOGO JAZYKA. <https://ruscorpora.ru/new/>. [online]. [cit. 1. 8. 2021]. 
дефинисање видског и валенцијског потенцијала деривата глагола волети уз порећење са овде презентованим материјалом. Након тога би се креирала база за проширење анализе како на скупину глагола емоционалних односа у ширем смислу, тако и на друге подгрупе емоционалне глаголске лексике.

\section{Литература:}

BALEK, T.: Morfosintaksičke i pragmatičke osobine glagola ljubit'(sja) i voleti (se) kao eksponenata glagola sa značenjem pozitivnih osećanja u ruskom i srpskom jeziku. Philologia Mediana, 2021, br. 13, s. 739-755. ISSN 1821-3332.

ČERNYŠEV, V. I.: Slovar' sovremennogo russkogo literaturnogo jazyka. Moskva-Leningrad: Iz-vo Akademii Nauk SSSR, 1951, t. 2.

ČERNYŠEV, V. I.: Slovar' sovremennogo russkogo literaturnogo jazyka. Moskva-Leningrad: Iz-vo Akademii Nauk SSSR, 1958, t. 7 .

ČERNYŠEV, V. I.: Slovar' sovremennogo russkogo literaturnogo jazyka. Moskva-Leningrad: Iz-vo Akademii Nauk SSSR, 1960, t. 10.

ČERNYŠEV, V. I.: Slovar' sovremennogo russkogo literaturnogo jazyka. Moskva-Leningrad: Iz-vo Akademii Nauk SSSR, 1961, t. 12.

DOVGAL', A. V. - ŠEPELEVA, Ju. A.: Semantičeskije osobennosti glagolov so značenijami 'èmocional'noje sostojanije' i 'èmocional'noje otnošenije’ v anglijskom jazyke. In: Val'tèr, Ch. et al. (ed.): Acta Germano-Slavica. Mahìleŭ: MhDU, 2015, № 6, s. 48-52. ISBN 978-985-568-038-4.

IORDANSKAJA, L. N.: Popytka leksikografičeskogo tolkovanija gruppy russkich slov so značenijem čuvstva. Mašinnyj perevod i prikladnaja lingvistika, 1970, № 3, s. 3-26.

JEVGEN'JEVA, A. P.: Slovar' russkogo jazyka: v 4-ch tomach. Moskva: Russkij jazyk Poligrafresursy, 1999, <http://feb-web.ru/feb/mas/mas-abc/default.asp >. [online] [cit. 1. 8. 2021].

LJU, È - ŠEREMET'JEVA, Je. S.: Metatekstovyj operator «mjagko govorja»: specifika funkcionirovanija. Litera, 2021, № 5, s. 59-70. ISSN 2409-8698.

NACIONAL'NYJ KORPUS RUSSKOGO JAZYKA. <https://ruscorpora.ru/new/>. [online]. [cit. 1. 8. 2021].

PADUČEVA, Je. V.: Dinamičeskije modeli v semantike leksiki. Moskva: Jazyki slavjanskoj kul'tury, 2004. ISBN 5-94457-161-6.

SKOK, P.: Etimologijski rječnik hrvatskoga ili srpskoga jezika. Knjiga druga K - poni ${ }^{1}$. Zagreb: Jugoslavenska akademija znanosti i umjetnosti, 1972. ISBN 86-407-0064-8. SKOK, P.: Etimologijski rječnik hrvatskoga ili srpskoga jezika. Knjiga treća poni² Ž. Zagreb: Jugoslavenska akademija znanosti i umjetnosti, 1973. ISBN 86-407-0064-8. 
STANKOVIĆ, B.: Rusko-srpski rečnik. Novi Sad: Prometej, 2008, 1001 s. ISBN 987-86$-515-0300-2$.

TICHONOV, A. N.: Novyj slovoobrazovatel'nyj slovar' russkogo jazyka. Moskva: AST, 2014. ISBN 978-5-17-082826-5.

TOLSTOJ, L. N.: Ana Karenjina. <http://www.umetnickaskolanis.com/wp-content/ uploads/2017/o9/Lav-Nikolajevic\%CC\%8C-Tolstoj-Ana-Karenjina.pdf>. [online]. [cit. 7. 7. 2021].

TOLSTOJ, L. N.: Anna Karenina. <https://ilibrary.ru/text/1099/index.html>. [online]. [cit. 7. 7. 2021].

TOŠOVIČ, B.: Sposoby glagol'nogo dejstvija v serbskom, chorvatskom i bošnjackom jazykach. Katowice: Wydawnictwo Uniwersytetu Śląskiego, 2009. <https://www. gewi.uni-graz.at/gralis-alt/GraLiS_TB/Bibliographie/pdf/Tosovic_Sposoby_gl_ dejstvija_BKS_20o8b.pdf>. [online]. [cit. 2. 8.2021].

VASIL’JEV, L. M.: Semantika russkogo glagola. Moskva: Vysšaja škola, 1981.

\section{About the author}

\section{Tijana Balek}

University of Novi Sad, Faculty of Philosophy, Department of Slavic Studies, Novi Sad, Serbia

tijana.balek@ff.uns.ac.rs 
